\title{
RECOMMENDATIONS TO BIM APPROACH FOR A BRAZILIAN INFRASTRUCTURE COMPANY
}

\author{
Fernanda V. Borges ${ }^{1}$, Aline V. Arroteia ${ }^{2}$, and Flavia R. de Souza ${ }^{3}$
}

\begin{abstract}
In recent years, Brazilian government issued a federal decree establishing the National Dissemination Strategy for Building Information Modelling (BIM) with the expectation that BIM will be disseminated in public works by 2028. In addition to this, the Brazilian Association of Technical Standards (ABNT) has set up a committee to generate and disseminate standardization involving the various aspects of BIM implementation. In this scenario, the objective of this paper is to investigate the BIM implementation process in a Brazilian government infrastructure studied company, and to understand how the Design as well the Consultant Firms are facing the new demands about BIM. An exploratory research through qualitative and quantitative approaches was carried out by a case study. The qualitative approach was based on a set of interviews applied with Technical Professionals and the company's board that work at the studied company. The quantitative approach was held through an online survey questionnaire applied to the designer's base that work with the studied company. The analysis was also based on five different guides: BIM Project Execution Planning Guide, RICS Guide, CBIC Guide, EUBIM Handbook and European Construction Sector Observatory. As a result, the paper aims to deliver a set of practical recommendations in order to help the studied company define the demands for their designer's base so that bidding occur in the best possible way, and also to better its BIM implementation process.
\end{abstract}

Keywords: BIM, BIM implementation, Project management, Infrastructure, Civil Construction.

\section{INTRODUCTION}

This paper aims to understand how a Brazilian infrastructure company is implementing BIM in its processes and activities and to understand how the technical contractors (designers and consultants that work for the studied company) have received the new demands from the studied company.

The investigation arose due to the increasing importance and use of BIM in the construction sector and due to the publication of a Federal Decree that institutes BIM implementation in public projects until the year 2028. Also, there are already works in progress of the Brazilian Association of Technical Standards (ABNT) to generate BIM standardization.

The research method is based on qualitative and quantitative approaches and its result aims to support the studied company to define the BIM demands for their technical contractors accordingly so that bidding occur in the best possible way. Additionally, the study aims to support the BIM implementation process improvement of the studied company.

Architect and Urban Planner, University of Sao Paulo, Sao Paulo, Brazil, fevarella@gmail.com Architect and Urban Planner, University of Sao Paulo, Sao Paulo, Brazil, aline.arroteia@usp.br Civil Engineer, University of Sao Paulo, Sao Paulo, Brazil, flavia.souza@usp.br 


\section{BIM IMPLEMENTATION IN BRAZIL}

In 2018, the Brazilian government issued a Federal Decree establishing the National Dissemination Strategy for Building Information Modelling (BIM), called BIM BR, to promote an appropriate environment for investment in BIM and its diffusion in the country. Among the objectives of this action, there is the intention to diffuse BIM and its benefits, coordinate public sector structuration, stimulate BIM capacitation, encourage competition in the market, develop technical standards, guides and specific protocols for BIM adoption. A BIM BR Strategy Management Committee (CG-BIM) was created to implement the BIM BR Strategy and manage its actions. The expectation is that in 10 years (until 2028) the methodology will be disseminated in public works.

To assist the implementation, the requirements were staggered in three stages:

1. From January 2021: architecture and engineering models elaboration, clash detection, quantitative extraction and generation of graphic documentation;

2. From January 2024: models must include the execution planning of the work, budgeting and models update, and their as built information;

3. From January 2028: BIM implementation in the entire project's life cycle considering post-work activities, management and maintenance services after its completion.

In addition to the government's actions, the Brazilian Association of Technical Standards (ABNT) has set up a committee to generate and disseminate standardization involving the various aspects of BIM implementation.

Therefore, both the goals imposed by the government and the development of Technical Standards have set up the movement of Brazilian construction sector towards implementing BIM in public works.

\section{METHOD}

Qualitative and quantitative approaches were undertaken by a case study using a public infrastructure company located in Sao Paulo, Brazil. According to Yin (2015), the case study helps to understand complex social phenomena in their real-world context, and Martins (2012) states that the act of measuring research variables is the most striking feature of the quantitative approach. Furthermore, Martins (2012) indicates the possibility of combining different research approaches, enabling a better understanding of research problems.

The qualitative approach was based on structured interviews applied to two technical professionals who support the studied company's board. The interviews were carried out in July 2019 and intended to understand how the BIM implementation has held and which actions were underway.

The quantitative approach was held through an online survey questionnaire applied in January 2020 to the company's outsourcing base composed by Design and Consultancy firms. The questions were structured on the model presented by Liu et al. (2017), which made it possible to measure the contractors' BIM maturity. The survey's aims were to understand how much these firms and their Professionals understand BIM, in which stage their BIM implementation process are and how they have carried out this process. There were 56 contractors contacted from the studied company's base, of which 30 answered the questionnaire. The questionnaire had been available for two weeks. 


\section{BIM GUIDES}

Despite the reference to implement BIM within Brazilian context being the CBIC - BIM Implementation Collection for Builders and Developers (2016) collection, in order to base the discussion about the BIM implementation process of the studied company, other five international guides were analysed: BIM Project Execution Planning Guide (2010) from USA, RICS International BIM Implementation Guide (2015) from London, EUBIM Handbook (2016) from European Union, and European Construction Sector Observatory (2019) from European Union.

Specifically about CBIC collection (2016), these guides are part of the sectorial initiative based on the Federal Decree. These guides aim to build common understanding and language around BIM as well to share and promote the consistent introduction of BIM, encouraging wider use of developed standards and common principles, both in national and international levels.

Table 1 shows a summary of the main characteristics of each guide studied.

Table 1: Summary characteristics of BIM Guides.

\begin{tabular}{|c|c|c|c|c|c|}
\hline & $\begin{array}{l}\text { BIM Project } \\
\text { Execution Planning } \\
\text { Guide }\end{array}$ & RICS & CBIC & $\begin{array}{l}\text { EUBIM } \\
\text { Handbook }\end{array}$ & $\begin{array}{l}\text { European } \\
\text { Construction } \\
\text { Sector } \\
\text { Observatory }\end{array}$ \\
\hline Year & 2010 & 2015 & 2016 & 2016 & 2019 \\
\hline Scope & $\begin{array}{l}\text { All construction } \\
\text { projects }\end{array}$ & $\begin{array}{l}\text { All construction } \\
\text { projects }\end{array}$ & $\begin{array}{l}\text { Building } \\
\text { construction } \\
\text { companies and } \\
\text { developers }\end{array}$ & $\begin{array}{l}\text { Public } \\
\text { construction } \\
\text { projects }\end{array}$ & $\begin{array}{l}\text { All } \\
\text { construction } \\
\text { projects }\end{array}$ \\
\hline Origin & $\begin{array}{l}\text { Pennsylvania State } \\
\text { University } \\
\text { Department of } \\
\text { Architecture and } \\
\text { Engineering, } \\
\text { Charles Pankow } \\
\text { Foundation, The } \\
\text { Construction } \\
\text { Industry Institute, } \\
\text { The Partnership for } \\
\text { Achieving } \\
\text { Construction } \\
\text { Excellence (PACE) }\end{array}$ & $\begin{array}{l}\text { International BIM } \\
\text { Working Group of } \\
\text { the Royal Institution } \\
\text { of Chartered } \\
\text { Surveyors (RICS) - } \\
\text { London, including } \\
\text { consultants and } \\
\text { multinational } \\
\text { companies }\end{array}$ & $\begin{array}{l}\text { Brazilian } \\
\text { Construction } \\
\text { Industry } \\
\text { Chamber (CBIC) } \\
\text { and the National } \\
\text { Service of } \\
\text { Industrial } \\
\text { Learning (SENAI) }\end{array}$ & $\begin{array}{l}\text { Collaboration } \\
\text { between } \\
\text { public sector } \\
\text { organizations } \\
\text { in } 21 \\
\text { countries of } \\
\text { the European } \\
\text { Union }\end{array}$ & $\begin{array}{l}\text { Around } 32,000 \\
\text { permanent and } \\
\text { contract } \\
\text { employees, } \\
\text { from } 28 \\
\text { countries of the } \\
\text { European } \\
\text { Union, work in } \\
\text { the } \\
\text { Commission. } \\
\text { These include } \\
\text { policy officers, } \\
\text { researchers, } \\
\text { lawyers and } \\
\text { translators }\end{array}$ \\
\hline $\begin{array}{l}\text { Objecti } \\
\text { ves }\end{array}$ & $\begin{array}{l}\text { Provide a practical } \\
\text { manual that can be } \\
\text { used by project } \\
\text { teams to design } \\
\text { their BIM strategy } \\
\text { and develop a BIM } \\
\text { Project Execution } \\
\text { Plan. It defines } \\
\text { structured } \\
\text { procedures for } \\
\text { implementing the } \\
\text { BIM Concept }\end{array}$ & $\begin{array}{l}\text { Highlights } \\
\text { international high- } \\
\text { level } \\
\text { principles around } \\
\text { how to implement } \\
\text { and use BIM in the } \\
\text { design, construction } \\
\text { and operation of the } \\
\text { built environment, } \\
\text { including facets of } \\
\text { procurement } \\
\text { management and } \\
\text { asset management }\end{array}$ & $\begin{array}{l}\text { Develop a clear } \\
\text { understanding of } \\
\text { BIM applications } \\
\text { by orienting its } \\
\text { application for } \\
\text { construction } \\
\text { companies and } \\
\text { developers; } \\
\text { Clarify, influence } \\
\text { and facilitate a } \\
\text { common } \\
\text { technological } \\
\text { platform between }\end{array}$ & $\begin{array}{l}\text { Build } \\
\text { common } \\
\text { understandin } \\
\mathrm{g} \text { and } \\
\text { language; } \\
\text { Share and } \\
\text { promote the } \\
\text { consistent } \\
\text { introduction } \\
\text { of BIM; } \\
\text { Encourage } \\
\text { wider use of } \\
\text { developed }\end{array}$ & $\begin{array}{l}\text { Looks at BIM } \\
\text { implementation } \\
\text { in the EU, } \\
\text { analyses the } \\
\text { drivers, } \\
\text { opportunities, } \\
\text { and challenges, } \\
\text { and draws } \\
\text { recommendatio } \\
\text { ns for EU } \\
\text { policy makers } \\
\text { and other } \\
\text { relevant actors }\end{array}$ \\
\hline
\end{tabular}




\begin{tabular}{|c|c|c|c|c|c|}
\hline & $\begin{array}{l}\text { BIM Project } \\
\text { Execution Planning } \\
\text { Guide }\end{array}$ & RICS & CBIC & $\begin{array}{l}\text { EUBIM } \\
\text { Handbook }\end{array}$ & $\begin{array}{l}\text { European } \\
\text { Construction } \\
\text { Sector } \\
\text { Observatory }\end{array}$ \\
\hline & & & $\begin{array}{l}\text { all construction } \\
\text { stakeholders }\end{array}$ & $\begin{array}{l}\text { standards and } \\
\text { common } \\
\text { principles }\end{array}$ & $\begin{array}{l}\text { on how to } \\
\text { support and } \\
\text { foster the } \\
\text { adoption of } \\
\text { BIM by the } \\
\text { construction } \\
\text { industry }\end{array}$ \\
\hline $\begin{array}{l}\text { Concep } \\
\text { tual } \\
\text { approa } \\
\text { ch }\end{array}$ & $\begin{array}{l}\text { Focus on } \\
\text { implementation } \\
\text { and } \\
\text { operationalization } \\
\text { of the BIM concept }\end{array}$ & $\begin{array}{l}\text { Focus on giving } \\
\text { recommendations to } \\
\text { implement BIM, } \\
\text { considering its main } \\
\text { processes }\end{array}$ & $\begin{array}{l}\text { Focus on } \\
\text { application in all } \\
\text { project life cycle } \\
\text { phases, not only } \\
\text { for buildings but } \\
\text { also } \\
\text { infrastructure } \\
\text { and industrial } \\
\text { projects }\end{array}$ & $\begin{array}{l}\text { Focus on } \\
\text { implementing } \\
\text { BIM } \\
\text { recommendat } \\
\text { ions at } \\
\text { strategic and } \\
\text { operational } \\
\text { levels }\end{array}$ & $\begin{array}{l}\text { Focus on giving } \\
\text { recommendatio } \\
\text { ns to foster } \\
\text { BIM } \\
\text { implementation } \\
\text { and } \\
\text { digitalization } \\
\text { through } \\
\text { country case } \\
\text { studies analysis }\end{array}$ \\
\hline Results & $\begin{array}{l}\text { The Guide } \\
\text { provides a } \\
\text { structured } \\
\text { procedure for } \\
\text { creating and } \\
\text { implementing a } \\
\text { BIM Project } \\
\text { Execution Plan, } \\
\text { through four steps: } \\
\text { 1. Identify high } \\
\text { value BIM uses } \\
\text { during project } \\
\text { planning, design, } \\
\text { construction and } \\
\text { operational phases } \\
\text { 2. Design the BIM } \\
\text { execution process } \\
\text { by creating process } \\
\text { maps } \\
\text { 3. Define the BIM } \\
\text { deliverables in the } \\
\text { form of } \\
\text { information } \\
\text { exchanges } \\
\text { 4. Develop the } \\
\text { infrastructure in } \\
\text { the form of } \\
\text { contracts, } \\
\text { communication } \\
\text { procedures, } \\
\text { technology and } \\
\text { quality control to } \\
\text { support the } \\
\text { implementation }\end{array}$ & $\begin{array}{l}\text { Provides } \\
\text { recommendations for } \\
\text { accepted good } \\
\text { practice as followed } \\
\text { by competent and } \\
\text { conscientious } \\
\text { practitioners. } \\
\text { Gives an overview of } \\
\text { BIM as technology, } \\
\text { the use of BIM in } \\
\text { project delivery and } \\
\text { implications of BIM } \\
\text { on organizations }\end{array}$ & $\begin{array}{l}\text { It presents first a } \\
\text { guide named } \\
\text { "The } 10 \text { reasons } \\
\text { to evolve with } \\
\text { BIM" followed by } \\
\text { five others guides } \\
\text { divided into: } \\
\text { 1. BIM } \\
\text { fundamentals } \\
2 . \text { BIM } \\
\text { implementation } \\
\text { 3. BIM } \\
\text { collaboration and } \\
\text { integration } \\
\text { 4. BIM workflows } \\
\text { 5. BIM contract } \\
\text { types }\end{array}$ & $\begin{array}{l}\text { Policy, } \\
\text { strategic and } \\
\text { implementati } \\
\text { on } \\
\text { recommendat } \\
\text { ions for } \\
\text { introducing } \\
\text { BIM to public } \\
\text { stakeholders } \\
\text { and } \\
\text { encouraging } \\
\text { its use. } \\
\text { Includes } \\
\text { General } \\
\text { Guidance and } \\
\text { Action } \\
\text { Recommenda } \\
\text { tions }\end{array}$ & $\begin{array}{l}\text { It brings } \\
\text { lessons learnt } \\
\text { from case } \\
\text { studies in } \\
\text { countries } \\
\text { across } \\
\text { European } \\
\text { Union. These } \\
\text { lessons learnt } \\
\text { include } \\
\text { recommendatio } \\
\text { ns for all } \\
\text { construction } \\
\text { value chain, } \\
\text { such as BIM } \\
\text { policies and } \\
\text { instruments; } \\
\text { Public } \\
\text { procurement; } \\
\text { Education, } \\
\text { research and } \\
\text { development; } \\
\text { BIM } \\
\text { standardization } \\
\text {; BIM industry } \\
\text { initiatives; BIM } \\
\text { capacity } \\
\text { building and } \\
\text { awareness } \\
\text { raising; and } \\
\text { Establishment } \\
\text { of BIM } \\
\text { guidelines and } \\
\text { standards }\end{array}$ \\
\hline
\end{tabular}




\section{FIELD RESEARCH}

\subsection{The Brazilian Infrastructure Studied company}

The studied company is part of the São Paulo Municipality structure and its operation aims to provide management to projects which are under the São Paulo City Infrastructure Department responsibility. It is a public company and its technical staff is responsible for project management services such as design and construction management followed by assisted operation. The design, consultancy, and construction services are outsourced through a bidding process which follows Brazilian laws.

In 2017 the company's board decided to structure a PMO (Project Management Office) and among its processes there would be a BIM laboratory which first aiming would be the BIM implementation within the company's processes and activities.

Into the PMO structuring context, the first step was to carry out an internal diagnosis to map the current project management processes used by the company, considering the hole company's process. Based on the process mapping, its comparison with the needed BIM operation process was possible. In the meantime, the company studied and looked to deepen its knowledge about BIM, attending conceptual courses, participating in conferences on the subject as well benchmarking.

The diagnosis answered that the company's biggest issue refers to the scope definition of projects. According to the company's interpretation, the issue was a consequence of bidding information problems, including the Reference Term. In principle, the Reference Term needs to allow a more efficient bidding process. On the other hand, once the projects' scopes had been poorly defined, as consequence, the definition of Reference Terms has usually presented a set of technical lacks which allows serious problems for the bidding processes.

Therefore, based on the diagnosis answer and the BIM implementation goal, an internal understanding of the main expected benefits from BIM implementation was carried out. Among them, the expected benefits are focused on the bidding process, project management, efficiency for design and consultancy contracting process, including the quality increasing of services provided as well as better results about cost, time and quality of the final products; internal team development; increasing the quality of design, including compatibility among systems and solutions; agility increasing on the analysis, including the technical approval aspects into the projects context; improving the relationship with stakeholders; reliable and precise quantitative extraction aiming better quality of costs definition and control; increased agility and transparency in the execution of the construction works; traceability and transparency of information; reduction of contractual additives; to produce models that assist in asset management and maintenance process; to provide assertive compatibility of macro solutions with other companies that have interference in the city (for instance, the light, water and transportation companies); and identify new demands to BIM implementation and BIM process

To achieve these benefits, a list of priority actions was created, which includes the improvement of project's scope process definition; the creation of an information and communication flow suitable with BIM process; the improvement of stakeholder management process, including their management; to contract specialized consultants to assist the BIM implementation process; to provide formal education about BIM and also provide training focused on related tools for the team involved with BIM implementation; to purchase computers and equipment compatible with BIM demands; to purchase BIM 
software needed to visualize models to extract information and make the necessary projects' analysis; to create a Standard Book for Contracting (services in general) which describes the biding process considering BIM process; to create a Reference Term for bidding process that will be suitable to BIM process, in which there will be all the specifications of product or service to contract; and carry out a Pilot Project through the application of the BIM Contracting Book and the BIM Reference Term. The expected benefits from each action planned are described in Table 2. According to the description, some of them are in progress while others have not initiated yet and just some of them are completed. The expected benefits from each action planned are described in Table 2.

Table 2: Actions and Expected Benefits by BIM implementation.

\begin{tabular}{|c|c|c|}
\hline Actions & Status & Expected Benefits \\
\hline Improve the scoping process & In progress & $\begin{array}{l}\text { More efficient bids. } \\
\text { Reduction of contractual additives; }\end{array}$ \\
\hline $\begin{array}{l}\text { Create an information and } \\
\text { communication flow for } \\
\text { processes including BIM }\end{array}$ & Completed & $\begin{array}{l}\text { Traceability and transparency of } \\
\text { information; } \\
\text { Increased agility and transparency in } \\
\text { the execution of the works. }\end{array}$ \\
\hline $\begin{array}{l}\text { Improve requirements identification } \\
\text { process }\end{array}$ & In progress & $\begin{array}{l}\text { More efficient bids; } \\
\text { Better relationship with } \\
\text { stakeholders; } \\
\text { Compatibility of solutions with } \\
\text { other companies. }\end{array}$ \\
\hline $\begin{array}{l}\text { Hire consultants to assist the BIM } \\
\text { implementation process }\end{array}$ & To be initiated & $\begin{array}{l}\text { Identify new demands to BIM } \\
\text { implementation and BIM process; } \\
\text { Increased project compatibility. }\end{array}$ \\
\hline $\begin{array}{l}\text { Provide conceptual and tool training } \\
\text { to the professionals involved }\end{array}$ & To be initiated & $\begin{array}{l}\text { Team development } \\
\text { Better quantitative extraction. }\end{array}$ \\
\hline Purchase more powerful computers & In progress & More efficient project analysis. \\
\hline Purchase BIM software & In progress & $\begin{array}{l}\text { More efficient project analysis; } \\
\text { Better quantitative extraction. }\end{array}$ \\
\hline $\begin{array}{l}\text { Create a Standard Book for BIM } \\
\text { Contracting }\end{array}$ & In progress & $\begin{array}{l}\text { More efficient bids; } \\
\text { Reduction of contractual } \\
\text { additives. }\end{array}$ \\
\hline $\begin{array}{l}\text { Create a Reference Term for BIM } \\
\text { bidding }\end{array}$ & In progress & $\begin{array}{l}\text { More efficient bids; } \\
\text { More efficient contract } \\
\text { management; } \\
\text { Reduction of contractual } \\
\text { additives. }\end{array}$ \\
\hline $\begin{array}{l}\text { Carry out a Pilot Project with the } \\
\text { application of the BIM Contracting } \\
\text { Book and the BIM Reference Term }\end{array}$ & To be initiated & $\begin{array}{l}\text { Identify new demands to BIM } \\
\text { implementation and BIM process; } \\
\text { Models that assist in asset } \\
\text { management and maintenance. }\end{array}$ \\
\hline
\end{tabular}

Through the course of the actions, the studied company has experienced some difficulties in the BIM implementation, which includes the team's eagerness to model rather than to understand BIM's gains; team does not work exclusively in BIM activities, generating problems of availability and interest; cost constraints of the BIM implementation project; difficulties in complying with existing legislation, once regulatory bodies still require physical project boards to make financial measurements, and; finding a project to use as Pilot for the BIM implementation in the company. 


\subsection{BIM Implementation by Contractors}

Based on current discussions about BIM implementation and also taking into account the characteristics of the studied company, an effective strategy to implement BIM through must involve the technical outsourcing parts (design and consultancy firms).

The survey allowed understanding the level of knowledge about BIM of researched firms, how these firms have prepared themselves for the Brazilian Government BIM Decree and how they received the demands about BIM implementation from the studied company.

The survey was a type of controlled one, since it was answered by technically experienced professionals which allows appropriate inferences from the analysis and consideration of survey results. The survey was carried out through a structured questionnaire that was sent in January 2020 which were structured into four parts:

4. 1. Sample characterization;

5. 2. General questions to diagnose the respondents' knowledge about BIM;

6. 3. Questions about the BIM implementation process;

7. 4. Questions about the respondents' awareness referring to the BIM implementation of studied company.

According to Table 3, the controlling promoted on the sample was effective since all survey respondents are technically qualified and have consistent industry experience to answer the questions.

Table 3: Sample Characterization - Educational Profile.

\begin{tabular}{ll}
\hline Educational Profile & Amount \\
\hline Bachelor science (Engineer or Architect) & 14 \\
Master's in science & 8 \\
Specialization in BIM & 2 \\
Specialization in Design Management & 6 \\
Total & 30 \\
\hline
\end{tabular}

About the sample's professional profile, $80 \%$ have been working in the construction industry for 10 years or more, as illustrated in Figure 1, 13\% are professionals in the intermediate stage of their technical careers and just 3\% of sample are from Juniors Professionals community.

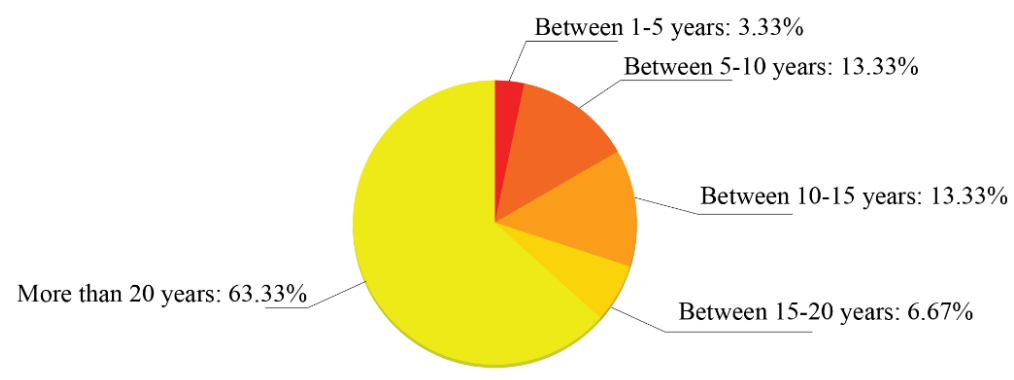

Figure 1: Professional Profile. 
According to Figure 2, the projects developed by the respondents are spread throughout Brazil, South America Countries and in some cases also abroad the continent. Again, the question was the type of multi choice one and despite $70 \%$ of respondents indicates acting in Southwest Region, the acting in other regions are balanced.

The concentration of projects in Southwest region is highly associated with their expertise in Sanitation and Urban Maintenance, Transport Infrastructure Projects, once the biggest Brazilian cities are located in Southwest (São Paulo, Rio de Janeiro and Belo Horizonte).

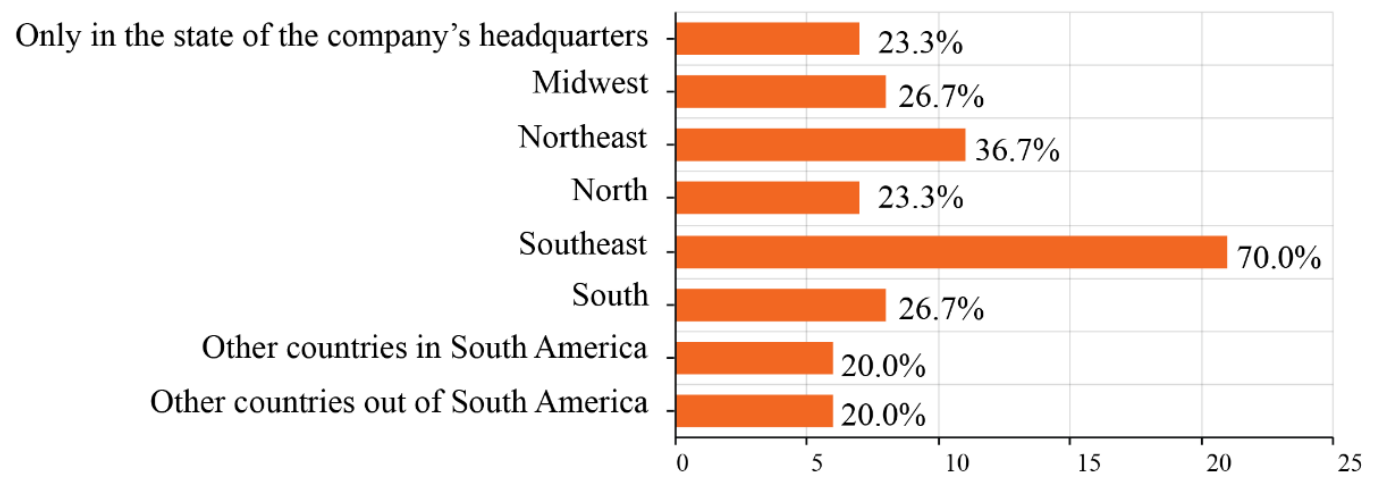

Figure 2: Regions of contractors' developed projects.

In order to evaluate the respondents' knowledge about BIM, the survey comprised a question focused on the meaning of BIM. It was a multi choice question and according Figure 3, the answers are concentrated in the following meanings: Process of information generation and management; Process focused on produce information to support the Project Management; Process to quantity survey analysis; Set of technologies, process and policies to promote collaboration among the Project's Stakeholders; Application of Modelling Tools; Process for Design Management, including clash; Process for integrated and collaborative design practice .

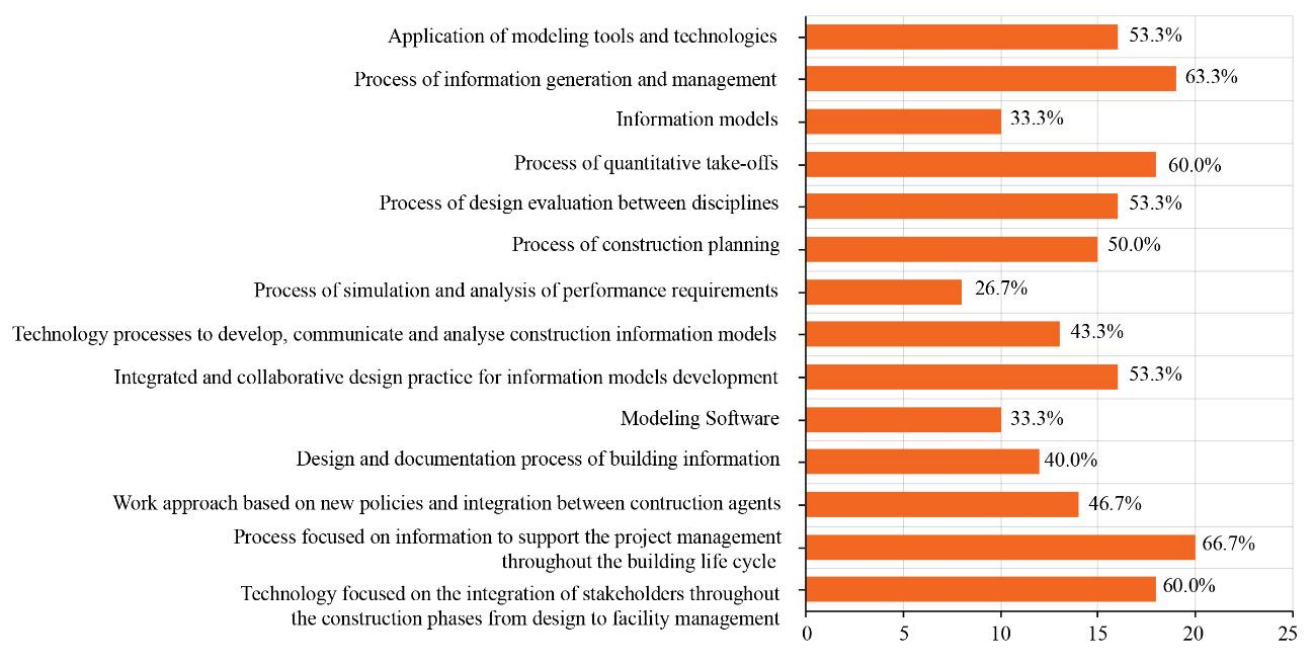

Figure 3: Contractors' knowledge about BIM.

Regarding the BIM implementation, Figure 4 shows 36,7\% of the respondents reported their firms as in an initial phase and $20 \%$ is evaluating the possibility of implementing BIM. 
Among the respondents, $10 \%$ is in an advanced phase and $13,3 \%$ is not planning to implement BIM at all.

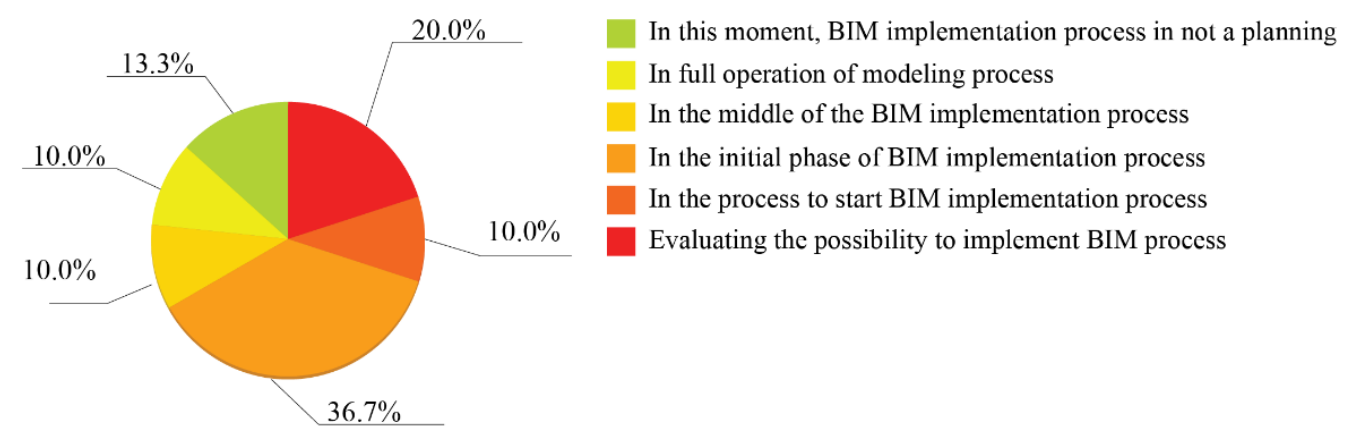

Figure 4: Current contractors`stage in BIM implementation.

The relevance level of actions along BIM implementation process was mapped. The vast majority evaluate the training of the team in BIM software as highly relevant, followed by the understanding about what are the main clients' objectives in relation to modelling. Items such as operational analysis, investments planning, and competences discussion are also questioned and about them, the answers indicated a balanced evaluation.

As the awareness about the BIM implementation process in action of the studied company, which represents a relevant client for the approached contractors, 76,7\% answered to be aware. However, the portion which is not aware, represents 23,33\%, which is almost the fourth part of total base of outsourcing contractors of the studied company, what indicates the company's necessity to review the strategy of involvement of their technical contractors in its BIM implementing process.

According to Figure 5, referring to policies and guidelines, the data has indicated as highly relevant the clarifying of new contractual guidelines, the awareness about the information exchange process as well collaboration. Finally, the guidelines for delivering was indicated as equally relevant by contractors.

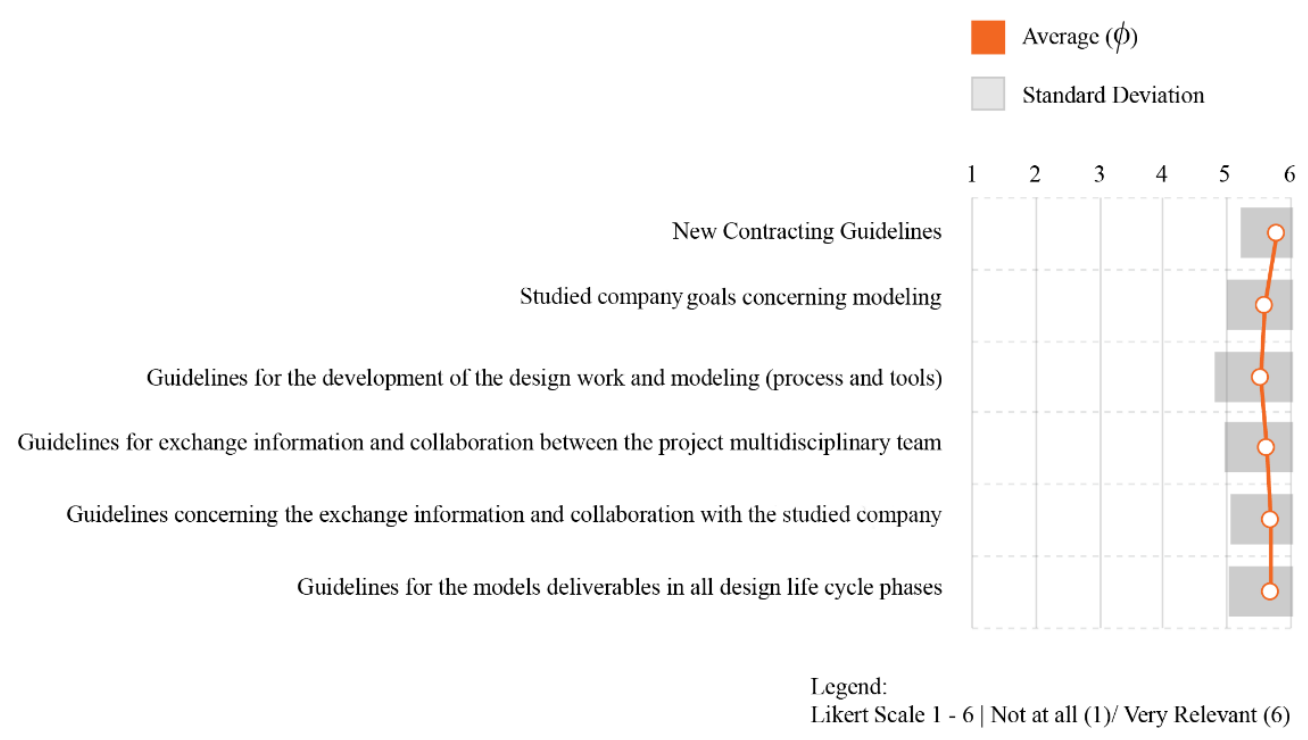

Figure 5: Relevance of clarifications made by the company about BIM implementation. 
Regarding the benefits that the BIM implementation can bring, the contractors have put themselves as follows:

- Most contractors believe that: it helps in carrying out the feasibility study and conception of the project; facilitates the analysis and decision-making process; has positive impact on scope definition, project quality and communication; assists the collaboration between project disciplines, anticipating problems and interferences; assists in the quantitative extraction for cost estimates during the design phase; enhances the improvement of operation quality of the projects; and assists in generating as-built documents;

- Most contractors think it has medium relevance: positive impact on project costs and deadlines;

- There was no consensus on the impacts of implementing BIM on increasing the designer's approach to the construction teams.

Regarding the challenges that the BIM implementation may bring, contractors have put themselves as follows:

- Most contractors fully agree that: there are difficulties on finding professionals who have the necessary competences for BIM operation or even, training professionals in BIM concepts; difficulties due to the different levels of maturity among the agents participating in the project; difficulties in implementing organizational and cultural changes; difficulties regarding the use of information; difficulty with legal guidelines regarding ownership and production of documentation; resistance to changes in processes of those involved; difficulty in the high cost of implementation; and difficulty in defining contracts based on the concept of information modelling.

- Most contractors partially agree that: it makes it difficult to form project teams; hinders effective collaboration between the parties involved; and makes it difficult to manage the models.

- There was no consensus on the difficulties of implementing BIM on the clear understanding of the responsibilities of each involved.

Regarding to the analysis of the relevance among Technology, Processes and People within BIM implementation process, the majority of respondents consider People the most important aspect, followed by Technology and finally, Process is pointed out as the less relevant aspect as illustrated in Figure 6. 


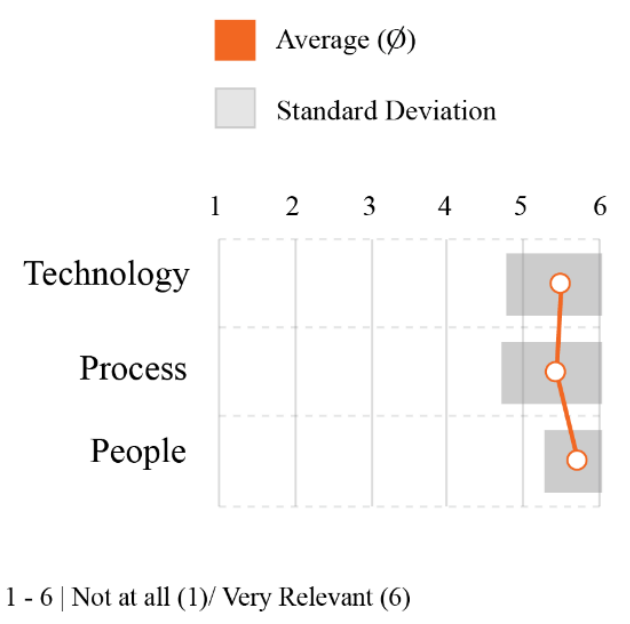

Figure 6: Relevance of Technology, Process and People in BIM implementation.

Specifically about the People aspect, respondents consider the attitude of the contractors and the readiness to practice new workflows, processes and uses of technologies are the most important aspects for the implementation process, as illustrated in Figure 7.

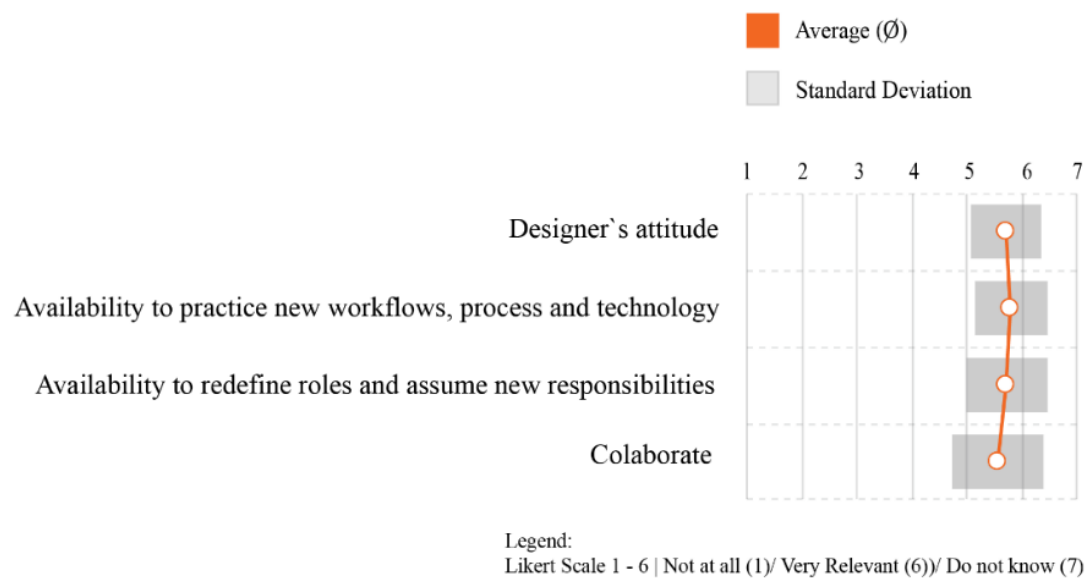

Figure 7: People aspects in BIM implementation.

Within the Technology aspect, Figure 8 indicates that the respondents consider the software functionality, system compatibility, management of model creation, and management of model sharing are the most important aspects that allow implementation process in appropriate way. 


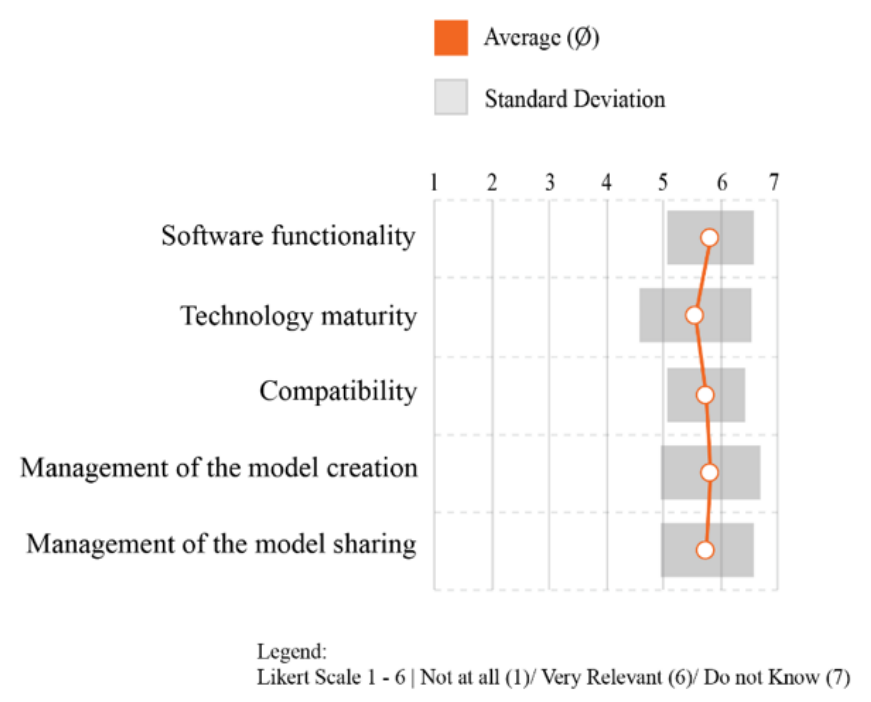

Figure 8: Technology aspects in BIM implementation.

Finally, about the Processes aspect, Figure 9 shows the average of how the respondents consider learning and experience in BIM processes, the format for exchanging information, and collaboration among the agents are the most important aspects.

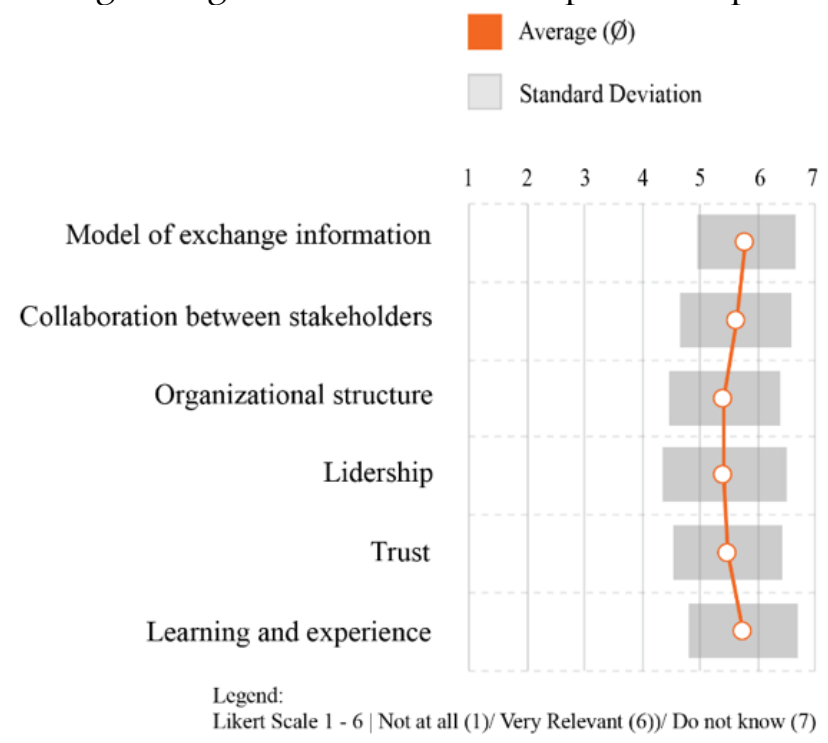

Figure 9: Processes aspects in BIM implementation.

\section{DISCUSSION}

Two sets of discussions were held. The first one is focused on the comparative analysis of the studied company's actions and the Guides' recommendations. The second one is based on the comparative analysis of the studied company's actions and the survey results. From these analyses, recommendations were created for the studied company aiming to improve its BIM implementation. 


\subsection{BIM Implementation: Studied company's actions and Guides' Recommendations}

The applicable Guides' recommendations served as a parameter for comparison with the BIM implementation actions in the contracting company previously presented.

For each recommendation, it was assessed whether the studied company already has planned actions that meet that certain recommendation, and if nothing has been foreseen, new recommendations were suggested according the content of Table 5.

Table 5: Recommended actions to the studied company through the Guides' analysis.

\begin{tabular}{|c|c|c|}
\hline Guides' Recommendations & $\begin{array}{l}\text { Studied company has } \\
\text { planned actions related } \\
\text { to the Guides' } \\
\text { recommendation? }\end{array}$ & $\begin{array}{l}\text { Recommended actions to be taken by } \\
\text { the studied company }\end{array}$ \\
\hline Make a Business Case & No & $\begin{array}{l}\text { Generate a business case for the BIM } \\
\text { implementation project, with all the } \\
\text { necessary analyzes. }\end{array}$ \\
\hline Identify BIM goals and uses & Yes & $\begin{array}{l}\text { Review goals and uses whenever } \\
\text { necessary. }\end{array}$ \\
\hline $\begin{array}{l}\text { Design BIM project execution } \\
\text { process* }\end{array}$ & No & $\begin{array}{l}\text { Create a BIM project execution } \\
\text { process. }\end{array}$ \\
\hline $\begin{array}{l}\text { Define project`s life cycle } \\
\text { phases }\end{array}$ & Yes & $\begin{array}{l}\text { Review project's life cycle whenever } \\
\text { necessary. }\end{array}$ \\
\hline $\begin{array}{l}\text { Define supporting } \\
\text { infrastructure for BIM } \\
\text { implementation }\end{array}$ & Yes & $\begin{array}{l}\text { Review infrastructure support } \\
\text { whenever necessary. }\end{array}$ \\
\hline Define contract policy & No & Define and disclose contract policy. \\
\hline $\begin{array}{l}\text { Define information technology } \\
\text { policy }\end{array}$ & Yes & $\begin{array}{l}\text { Disclose information technology } \\
\text { policy. }\end{array}$ \\
\hline $\begin{array}{l}\text { Develop information exchange } \\
\text { and information needs* }\end{array}$ & Yes & $\begin{array}{l}\text { Disclose information and } \\
\text { communication flow. }\end{array}$ \\
\hline $\begin{array}{l}\text { Define interoperability and } \\
\text { communication procedures* }^{*}\end{array}$ & Partially & $\begin{array}{l}\text { Define interoperability procedures; } \\
\text { Disclose information and } \\
\text { communication flow. }\end{array}$ \\
\hline $\begin{array}{l}\text { Technology infrastructure } \\
\text { needs }\end{array}$ & Yes & $\begin{array}{l}\text { Review technology infrastructure } \\
\text { whenever necessary. }\end{array}$ \\
\hline Define model structure* & No & Define model structure processes. \\
\hline Define project deliverables* & Yes & $\begin{array}{l}\text { Review project deliverables whenever } \\
\text { necessary. }\end{array}$ \\
\hline $\begin{array}{l}\text { Identify strategies and specific } \\
\text { BIM requirements for the hiring } \\
\text { process }\end{array}$ & Partially & $\begin{array}{l}\text { Identify strategies and specific BIM } \\
\text { requirements for the hiring process; } \\
\text { Define and disclose the Reference } \\
\text { Term and the Contracting Book. }\end{array}$ \\
\hline Define delivery strategy & No & Define delivery strategy. \\
\hline Define project budget* & Yes & $\begin{array}{l}\text { Review project budget whenever } \\
\text { necessary. }\end{array}$ \\
\hline $\begin{array}{l}\text { Establish teams and } \\
\text { stakeholder`s role and } \\
\text { responsibilities** }\end{array}$ & Yes & $\begin{array}{l}\text { Review teams and stakeholder`s role } \\
\text { and responsibilities whenever } \\
\text { necessary. }\end{array}$ \\
\hline $\begin{array}{l}\text { Define the quality control of } \\
\text { BIM models }\end{array}$ & No & $\begin{array}{l}\text { Define the quality control of BIM } \\
\text { models. }\end{array}$ \\
\hline $\begin{array}{l}\text { Develop pilot studies of BIM } \\
\text { implementation and goals }\end{array}$ & Partially & Put into practice the Pilot Project. \\
\hline
\end{tabular}




\subsection{BIM Implementation Understanding: Studied Company $\mathrm{x}$ Contractors perspective}

In order to understand whether the studied company and its technical contractors are in line about the BIM implementation, a comparative analysis was carried out. The survey results were placed alongside the main actions of the studied company, and the understanding of BIM, the view of the expected benefits and the view of the existing challenges for implementation were analysed.

\subsubsection{BIM Vision}

Regarding the understanding about what BIM is, from conceptual perspective, it is possible to realize that contractors are in line with the studied company's understating, since most respondents identify BIM as a process to generate information models, which must include enough information to support the management of all processes throughout the project's life cycle.

Also, most respondents understand that BIM enables collaborative work, improves construction management and it assists in obtaining quantities and budgeting for construction. All of those aspects are listed benefits from the studied company about BIM implementation.

Nevertheless, some crucial aspects must be noted in order to review some implementations strategies which tends to impact the relation between the studied company and its technical contractors. For example, the ranking of relevant aspects along the implementation process attains the attention, since two extremes aspects appear as most relevant: Client Centricity as a strategic one and Software Training as operational. Even more worrying, the contractors pointed out the operational aspect (Software training) as more relevant than the strategic aspect.

The information allows to conclude that the contractors do not evaluate the BIM implementation process as a strategic one, although the significant amount investments (time, money, expertise, clients expectations, employee expectations and mainly their competences) involved in this process and probably the conclusion would be associated with the limited vision about how BIM tends to impact on the contractors business model.

According to the survey results, most of the contractors are concerned about the BIM implementation in their own companies, due to the demands of the context and also to provide high level services to their clients, which includes the studied company of this research.

As to balance lacking about the triad People, Process and Technology, since BIM could be defined as a set of technology supported by processes which is operated by people, and therefore the three aspects have equal relevance, the ranking evaluation approached in the question was purposeful in order to evaluate if the respondents are aware about the concepts which is behind BIM. Due to the answers, apparently the approached firms are not totally aware about the BIM concept.

On the other hand, the survey results indicated an alert to the studied company. One fourth of contractors are not aware about the BIM implementation process in the studied company, and this research analysis indicates how important is to review the communication protocols in order to make all contractors base aware about the BIM implementation process.

\subsubsection{Understanding of Studied Company's Needs}

Regarding the contractors' awareness about the studied company's BIM implementation, it is possible to conclude that the studied company needs to inform how its processes will 
impact the contracts. The survey results indicate that $73,3 \%$ of the respondents have not identified differences in contracting processes due to the BIM implementation, and 86,7\% of respondents understand that it is highly relevant clarifying the new contractual process.

For $80 \%$ of the respondents, it is very relevant to define the process about the information exchanging and the collaboration process within the project context.

Finally, for $76,67 \%$ of respondents, it is highly relevant to understand the guidelines about the models delivering process, mainly about the level of detailing of each design phase and which information must be contained by models. The studied company has not defined the modelling guidelines and also, they have not defined if changes will be promoted on the analysis process of deliverables. This action must be added to the studied company's actions of BIM implementation.

All mentioned aspects must be disclosed through the Reference Term model and the Contracting Book. The studied company must incorporate the issues and expectations pointed out by contractors in this document.

Table 6 summarizes the comparative analysis of the contractor's expectations and the products to be created by the studied company and shows recommended actions to be taken by the studied company in order to align with its contractors and provide a more efficient implementation process.

Table 6: Recommended actions to be taken by the studied company.

\begin{tabular}{|c|c|c|}
\hline Contractors expectations & Studied company's products & $\begin{array}{l}\text { Recommended actions to be taken by the } \\
\text { studied company }\end{array}$ \\
\hline $\begin{array}{l}\text { Need to know the } \\
\text { differences in the studied } \\
\text { company's hiring processes } \\
\text { and contractual guidelines } \\
\text { adopted }\end{array}$ & $\begin{array}{l}\text { Reference Term model, } \\
\text { Contracting Book, changes } \\
\text { in the projects' analysis }\end{array}$ & $\begin{array}{l}\text { Disclose to contractors products that are } \\
\text { being generated in the BIM } \\
\text { implementation }\end{array}$ \\
\hline $\begin{array}{l}\text { Need to know how the } \\
\text { information exchange and } \\
\text { collaboration process will be }\end{array}$ & $\begin{array}{l}\text { Information and } \\
\text { communication flow }\end{array}$ & $\begin{array}{l}\text { Disclose to contractors the information } \\
\text { and communication flow }\end{array}$ \\
\hline $\begin{array}{l}\text { Need to understand the } \\
\text { guidelines on the delivery of } \\
\text { the Models for each phase } \\
\text { of the project cycle }\end{array}$ & $\begin{array}{l}\text { No explicitly cited changes } \\
\text { in its process }\end{array}$ & $\begin{array}{l}\text { Define and disclose guidelines on the } \\
\text { delivery of the Models for each phase of } \\
\text { the project cycle }\end{array}$ \\
\hline
\end{tabular}

\subsubsection{Benefits Vision}

Regarding the benefits that BIM implementation can provide, a comparative analysis was made between the studied company's understanding and the contractors' understandings, as follows.

Both the studied company and most contractors believe BIM implementation will result on most assertive feasibility study and better quality of project conception. Table 7 summarizes the comparative analysis of the contractors and the studied company's perception of benefits with BIM implementation. 
Table 7: Benefits and recommended actions to be taken by the studied company.

\begin{tabular}{|c|c|c|c|}
\hline Benefit & $\begin{array}{l}\text { Studied } \\
\text { company's vision }\end{array}$ & $\begin{array}{l}\text { Contractors' } \\
\text { vision }\end{array}$ & $\begin{array}{l}\text { Recommended actions to be taken by the } \\
\text { studied company }\end{array}$ \\
\hline $\begin{array}{l}\text { Helps in carrying out the } \\
\text { feasibility study and project } \\
\text { conception }\end{array}$ & According & According & $\begin{array}{l}\text { Create a feasibility study process for } \\
\text { BIM projects }\end{array}$ \\
\hline $\begin{array}{l}\text { Facilitates the analysis and } \\
\text { decision-making process }\end{array}$ & According & According & $\begin{array}{l}\text { Create a periodic project data analysis } \\
\text { process, focusing on decision making }\end{array}$ \\
\hline $\begin{array}{l}\text { Has positive impact on } \\
\text { scope definition, project } \\
\text { quality and communication }\end{array}$ & According & According & $\begin{array}{l}\text { Keep its actions towards improving the } \\
\text { scoping process and putting into practice } \\
\text { the information and communication } \\
\text { flow created }\end{array}$ \\
\hline $\begin{array}{l}\text { Assists the collaboration } \\
\text { between project disciplines, } \\
\text { anticipating problems and } \\
\text { interferences }\end{array}$ & According & According & $\begin{array}{l}\text { Keep its actions to provide conceptual } \\
\text { and tool training to the professionals } \\
\text { involved and strengthen the vision of } \\
\text { collaboration }\end{array}$ \\
\hline $\begin{array}{l}\text { Assists in the quantitative } \\
\text { extraction for cost estimates } \\
\text { during the design phase }\end{array}$ & According & According & $\begin{array}{l}\text { Keep its actions to provide conceptual } \\
\text { and tool training to the professionals } \\
\text { involved }\end{array}$ \\
\hline $\begin{array}{l}\text { Enhances the improvement } \\
\text { of operation quality of the } \\
\text { projects }\end{array}$ & According & According & $\begin{array}{l}\text { Preview the operation quality needs in } \\
\text { the scoping definition }\end{array}$ \\
\hline $\begin{array}{l}\text { Assists in generating as- } \\
\text { built documents }\end{array}$ & Not mentioned & According & $\begin{array}{l}\text { Define as-built documents generation, } \\
\text { receipt and analysis process }\end{array}$ \\
\hline $\begin{array}{l}\text { Positive impact on project } \\
\text { costs and deadlines }\end{array}$ & According & According & $\begin{array}{l}\text { Keep its actions towards the positive } \\
\text { impacts in costs and time }\end{array}$ \\
\hline
\end{tabular}

\subsubsection{Challenges Vision}

Regarding the challenges that BIM implementation can generate, a comparative analysis was made between the studied company's understanding and the contractors' understandings.

Table 8 summarizes the comparative analysis of the contractors and the studied company's perception of challenges with BIM implementation, if they are aligned, and the recommended actions the studied company can put into practice for a better understanding between both. 
Table 8: Challenges and recommended actions to be taken by the studied company.

\begin{tabular}{|c|c|c|c|}
\hline Challenge & $\begin{array}{l}\text { Studied } \\
\text { company's vision }\end{array}$ & $\begin{array}{l}\text { Contractors' } \\
\text { vision }\end{array}$ & $\begin{array}{l}\text { Recommended actions to be taken by the } \\
\text { studied company }\end{array}$ \\
\hline $\begin{array}{l}\text { Finding or training } \\
\text { professionals in BIM } \\
\text { knowledge }\end{array}$ & According & According & $\begin{array}{l}\text { Keep its actions to provide conceptual } \\
\text { and tool training to the professionals } \\
\text { involved }\end{array}$ \\
\hline $\begin{array}{l}\text { Different levels of maturity } \\
\text { among the agents } \\
\text { participating in the project }\end{array}$ & According & According & $\begin{array}{l}\text { Enhance collaboration and involve } \\
\text { stakeholders in its processes definition } \\
\text { to help propitiate the sector BIM } \\
\text { maturity }\end{array}$ \\
\hline $\begin{array}{l}\text { Implementing } \\
\text { organizational and cultural } \\
\text { changes }\end{array}$ & According & According & $\begin{array}{l}\text { Create periodic disclosure of actions } \\
\text { about BIM implementation in the } \\
\text { organization, presenting examples of } \\
\text { benefits generated }\end{array}$ \\
\hline Use of information & According & According & $\begin{array}{l}\text { Put into practice the information and } \\
\text { communication flow to perceive needed } \\
\text { changes }\end{array}$ \\
\hline $\begin{array}{l}\text { Legal guidelines regarding } \\
\text { ownership and production } \\
\text { of documentation }\end{array}$ & According & According & $\begin{array}{l}\text { Define legal guidelines regarding } \\
\text { ownership and production of } \\
\text { documentation }\end{array}$ \\
\hline $\begin{array}{l}\text { Defining contracts based on } \\
\text { the concept of information } \\
\text { modeling }\end{array}$ & According & According & $\begin{array}{l}\text { Create a contract model including BIM } \\
\text { needs } \\
\text { Keep its actions to create a Contracting } \\
\text { Book }\end{array}$ \\
\hline $\begin{array}{l}\text { Resistance to changes in } \\
\text { processes of those involved }\end{array}$ & According & According & $\begin{array}{l}\text { Show value gained with the BIM use to } \\
\text { those involved }\end{array}$ \\
\hline $\begin{array}{l}\text { High cost of } \\
\text { implementation }\end{array}$ & According & According & $\begin{array}{l}\text { Revise and negotiate the budget for BIM } \\
\text { implementation, showing value to those } \\
\text { responsible for costs }\end{array}$ \\
\hline Form project teams & Not mentioned & According & $\begin{array}{l}\text { Show the value of BIM implementation } \\
\text { on team's daily practices } \\
\text { Provide BIM training (conceptual and } \\
\text { tools) }\end{array}$ \\
\hline Manage the models & Not mentioned & According & $\begin{array}{l}\text { Create a process for managing models in } \\
\text { a collaborative way }\end{array}$ \\
\hline
\end{tabular}




\subsubsection{Technology, Processes and People}

Regarding what contractors believe to be important in terms of technology, pro-cesses and people, Table 9 shows the recommendations.

Table 9: Recommendations about Technology, Processes and People.

\begin{tabular}{|c|c|c|}
\hline Theme & Items considered important by contractors & $\begin{array}{l}\text { Recommended actions to be taken by the } \\
\text { studied company }\end{array}$ \\
\hline People & $\begin{array}{l}\text { Attitude of the designers and the readiness } \\
\text { to practice new workflows, processes and } \\
\text { uses of technologies }\end{array}$ & $\begin{array}{l}\text { Share the processes created and } \\
\text { decisions made about BIM with the } \\
\text { designers, to increase collaboration }\end{array}$ \\
\hline Technology & Functionality of the software being used & $\begin{array}{l}\text { Share with designers the software that } \\
\text { will be used to analyze projects }\end{array}$ \\
\hline Technology & Compatibility of software & $\begin{array}{l}\text { Share with designers the software that } \\
\text { will be used to analyze projects }\end{array}$ \\
\hline Technology & Model creation management & Define model structure processes \\
\hline Technology & Model sharing management & Define model structure processes \\
\hline Processes & Learning and experience in BIM processes & $\begin{array}{l}\text { Create a collaborative platform for } \\
\text { learning and experience sharing }\end{array}$ \\
\hline Processes & Format for exchanging information & $\begin{array}{l}\text { Disclose information and } \\
\text { communication flow }\end{array}$ \\
\hline Processes & Collaboration between agents & $\begin{array}{l}\text { Create a collaborative platform for } \\
\text { learning and experience sharing }\end{array}$ \\
\hline
\end{tabular}

\section{CONCLUSIONS}

The research aimed to add value for BIM implementation process of the studied company through recommendations based on the Guides' best practices and also based on the diagnosis obtained through a survey applied with its contractors.

Table 10 summarizes all the recommendations that the studied company should take into account in its implementation process. The recommendations are taking into account that BIM implementation is a strategic process and must be undertaken through an inter organizational manner. In other words, if the technical contractors are not accordingly involved, the implementation tends to fail. 
Table 10: Recommended actions to the studied company.

Recommended actions to the contractor

Generate a business case for the BIM implementation project, with all the necessary analyzes

Create a feasibility study process for BIM projects

Review goals, uses and deliverables whenever necessary

Create a BIM project execution process

Create a periodic project data analysis process, focusing on decision making

Create periodic disclosure of actions about BIM implementation in the organization, presenting examples of benefits generated

Revise and negotiate the budget for BIM implementation, showing value to those responsible for costs

Review project's life cycle whenever necessary

Review infrastructure support and infrastructure whenever necessary

Define and disclose contract policy

Identify strategies and specific BIM requirements for the hiring process

Define legal guidelines regarding ownership and production of documentation

Create a contract model including BIM needs

Keep its actions to create a Contracting Book

Disclose information technology policy

Disclose information and communication flow

Create a collaborative platform for learning and experience sharing

Define delivery strategy

Define interoperability procedures

Define model structure processes for managing models in a collaborative way

Define as-built documents generation, receipt and analysis process

Define and disclose guidelines on the delivery of the Models for each phase of the project cycle

Define and disclose the Reference Term and the Contracting Book

Review project budget whenever necessary

Define the quality control of BIM models

Review teams and stakeholder`s role and responsibilities whenever necessary

Keep its actions towards the positive impacts in costs and time

Disclose to designers the products that are being generated in the BIM implementation

Keep its actions towards improving the scoping process

Keep its actions to provide conceptual and tool training to the professionals involved and strengthen the vision of collaboration

Enhance collaboration and involve stakeholders in its processes definition to help propitiate the sector BIM maturity

Share the processes created and decisions made about BIM with the designers, to increase collaboration

Share with designers the software that will be used to analyze projects

Show value gained with the BIM use to those involved

Show the value of BIM implementation on team's daily practices

Put into practice the Pilot Project

Some limitations of this research were identified such as the study with only one contracting company and the limited time to receive survey responses from the contractors. However, several opportunities for future works arose, such as analysing a larger number of studied companies; analysing the views of other stakeholders involved in BIM implementation, such as suppliers of material, construction companies, public agencies; and the study of needs for changes in legislation to meet the needs and specificities of BIM. 
These studies would also add to the understanding of the factors that can improve the relationship between stakeholders to improve the process of implementing BIM and, consequently, improve the final quality of projects.

\section{REFERENCES}

BRASIL Federal homepage (2019). Decree No 9.983 of August 2019. Provides for the National Dissemination Strategy for Building Information Modelling and establishes the Building Information Modelling Strategy Steering Committee. Available at: http://www.planalto.gov.br/ccivil 03/ ato2019-2022/2019/decreto/D9983.htm [Accessed 13 Sep. 2019].

BIM Project Execution Planning Guide (2010). Building SMART alliance. The Pennsylvania State University.

CBIC (2016). Coletânea Implementação do BIM para Construtoras e Incorporadoras. Câmara Brasileira da Indústria da Construção, Brasilia.

EUBIM Handbook (2016). EUBIM task group. European Union.

European Construction Sector Observatory (2019). European Commission. European Union.

Liu, Y., Nederveen, S., Hertogh, M. (2017). Understanding effects of BIM on collaborative design and construction: An empirical study in China. International Journal of Project Management. 35, pp. 686-698.

Martins, R. A. (2012). Abordagens Quantitativa e Qualitativa. In: Metodologia de Pesquisa em Engenharia de Produção e Gestão de Operações. Elsevier, Rio de Janeiro.

RICS (2015). International BIM Implementation Guide. Royal Institution of Chartered Surveyors, London.

SINAENCO (2019). Governo estabelece metas e prazos para implementação do BIM. Available at: http://sinaenco.com.br/noticias/governo-estabelece-metas-e-prazospara-implementacao-do-bim [Accessed 09 Sep. 2019].

Yin, R. K. (5. Ed.). (2015). Estudo de Caso: Planejamento e Métodos. Bookman, Porto Alegre. 